\title{
LITERASI DIGITAL SEBAGAI UPAYA PREVENTIF MENANGGULANGI HOAX
}

\author{
Anisa Rizki Sabrina \\ Departemen Ilmu Komunikasi, Universitas Gadjah Mada, \\ anisarsabrina@gmail.com
}

\begin{abstract}
One of the most important things in handling the false information circulation (hoax) in the posttruth era is increasing digital literacy. The goal is to give more control to the audience in interpreting messages in digital media. This paper will address the urgency of digital literacy, how it affects, and how to improve its skills in an attempt to overcome tricks. This research uses literature research methods in elaborating various literature in the form of books, journals, magazines, and literature relevant to the theme of writing. In this study, adjustments will be made to change the ecology of the media to encourage the novelty of previous studies, especially media literacy. Developing the definition of media literacy coined by $W$. James Potter, the author tries to divide the definition of digital literacy into three similar categories (by substituting media objects into digital technology) ie umbrella definition, process definition, and destination definition. Differences in level of literacy will affect the differences of individual control in the process of interpretation of existing information, especially information circulating in social media. On the one hand, social media can be seen as a step closer to democracy on the internet, and closing the digital divide between developing and developed countries. Access to information and social support can increase. But on the other hand, some negative cases are found in the realm of freedom of expression as the use of intense social media in society. Based on data from Diskominfo Jabar 2012, 92.4\% of hoax news distribution channels are found through social media. Therefore, the digital literacy relationship with the effort to overcome the deceit cases need to be more excavated, especially in the social media group with the most deceitful cases of microblog types (Twitter) and SNS (Facebook and Instagram). First, digital literacy as a necessity in the life of communication will be reviewed from the theoretical concepts to its importance. Secondly, this paper will discuss the relationship of digital literacy with the prevention of deceit in the post-truth era. Third, the digital literacy skill enhancement mechanism will be presented as a preventive measure. The relationship of digital literacy in the fight against false news lies in the role of the cognitive ability of the audience in the process of verifying information. In fact, to a higher level, digital literacy can help individuals provide alternative information about incorrectly confirmed information. When the control of social media content is difficult for media owners, governments, or other groups, digital literacy becomes the best solution. By promoting digital literacy, self-control over the use of social media can be done optimally. Increased digital literacy as a form of self-control into a solution to prevent the case of false information circulation (hoax) becomes more and more repetitive. Digital literacy can be an effective way to tackle false information (hoaxes) in the post-truth era, by introducing false news alerts, information verification procedures, and following up on the phenomenon of hoax information.
\end{abstract}

Keywords: digital literacy; hoax; post-truth era; Potter's media literacy. 


\begin{abstract}
ABSTRAK
Salah satu hal terpenting dalam menghadapi peredaran informasi palsu (hoax) di era post-truth adalah meningkatkan literasi digital. Tujuan memiliki kemampuan literasi digital ialah untuk memberikan kontrol lebih pada khalayak dalam memaknai pesan yang berlalu-lalang di media digital. Tulisan ini kemudian akan mengeksplorasi urgensi literasi digital, bagaimana pengaruhnya, serta cara meningkatkan kecakapannya sebagai upaya menanggulangi hoax. Studi ini menggunakan metode kepustakaan dalam mengelaborasi berbagai macam literatur baik berupa buku, jurnal, majalah, maupun literatur yang relevan dengan tema tulisan. Dalam studi ini, akan dilakukan penyesuaian terhadap ekologi media yang sudah berubah sehingga mendorong adanya unsur kebaruan dari studi terdahulu, khususnya literasi media. Mengembangkan definisi literasi media yang dicetuskan oleh W. James Potter, penulis mencoba membagi definisi literasi digital ke dalam tiga kategori serupa (dengan mengganti obyek media menjadi teknologi digital) yakni umbrella definition, definisi proses, dan definisi tujuan. Perbedaan tingkat literasi tentu saja akan berdampak pada perbedaan kontrol individu dalam proses interpretasi informasi yang ada, terutama informasi yang beredar di media sosial. Di satu sisi, media sosial dapat dilihat sebagai satu langkah lebih dekat dengan demokrasi pada internet, dan menutup kesenjangan digital antara negara berkembang dan negara maju. Akses pada informasi dan dukungan sosial dapat meningkat. Namun di sisi lain, beberapa kasus negatif ditemukan dalam ranah kebebasan berpendapat seiring intensnya penggunaan media sosial di masyarakat. Berdasarkan data dari Diskominfo Jabar 2012, saluran penyebaran berita hoax sebanyak 92,4\% ditemukan melalui media sosial. Oleh sebab itu, relasi literasi digital dengan upaya mengatasi kasus hoax perlu lebih banyak digali terutama pada golongan media sosial dengan kasus hoax terbanyak yaitu jenis mikroblog (Twitter) dan SNS (Facebook dan Instagram). Pertama, literasi digital sebagai sebuah keharusan dalam kehidupan komunikasi akan ditinjau mulai dari konsep teoritis hingga arti pentingnya. Kedua, tulisan ini akan membahas relasi literasi digital dengan upaya penanggulangan hoax di era post-truth. Ketiga, mekanisme peningkatan kecakapan literasi digital akan dihadirkan sebagai upaya preventif. Relasi literasi digital dalam memberantas berita palsu ini terletak pada peran kemampuan kognitif khalayak dalam proses verifikasi informasi. Bahkan, pada tingkatan yang lebih tinggi, literasi digital dapat membantu individu memberikan informasi alternatif atas informasi yang sudah terkonfirmasi kepalsuannya. Bila kontrol konten media sosial rasanya sulit dilakukan oleh pemilik media, pemerintah, maupun kelompok lainnya, literasi digital adalah salah satu solusinya. Dengan menggalakkan literasi digital, pengendalian diri terhadap penggunaan media sosial dapat dilakukan secara optimal. Peningkatan literasi digital sebagai bentuk self control menjadi solusi untuk mencegah kasus peredaran informasi palsu (hoax) menjadi berulang dan semakin banyak. Literasi digital dapat menjadi cara yang efektif untuk menanggulangi informasi palsu (hoax) di era post-truth, dengan mengenalkan tanda-tanda berita palsu, prosedur verifikasi informasi, hingga menindaklanjuti informasi yang kiranya masuk kategori hoax.
\end{abstract}

Kata-kata Kunci: era post-truth; hoax; literasi digital; literasi media Potter. 


\section{PENDAHULUAN}

Menjamurnya berita palsu/hoax yang beredar pada media sosial di Indonesia seakan menjadi mata rantai yang tak ada ujungnya. Konten tersebut senantiasa diproduksi, direproduksi, kemudian disebarkan secara terus menerus hingga menjadi sebuah fenomena dan kultur yang biasa saja. Permasalahan ini sejatinya adalah buah dari euforia media berekspresi yang baru, yang memungkinkan kita untuk berujar dan membuat konten apapun tanpa terikat tatanan etika kehidupan yang baku. Seakan kehidupan kita di media sosial berjalan secara terpisah dengan yang kita jalani pada dunia nyata.

Media sosial seperti Facebook, Twitter, Instagram, Snapchat, atau Whatsapp adalah tempat dimana gosip, breaking news, dan informasi yang sedang ramai dibicarakan khalayak cepat menyebar. Facebook sendiri memiliki 1,55 milyar pengguna aktif pada 2016, yang setiap penggunanya menghabiskan paling tidak 20 menit per hari untuk membaca informasi terbaru pada lini masa mereka. Lebih jauh, populasi pengguna ini akan terus meningkat, hingga diprediksi pengguna aktif media sosial di seluruh dunia akan mencapai 2,72 milyar pada 2029, sekitar sepertiga dari populasi dunia (Roese, 2018:314).

Hari ini, media sosial lebih berfungsi sebagai tempat pertemuan khalayak untuk bertukar berita, potongan-potongan informasi dan rekomendasi satu sama lain. Tersedianya tempat pertemuan dengan aktivitas konektif dengan kadar yang tinggi inilah yang membedakan media sosial dengan media konvensional lainnya (Van Dijck, 2013:62). Sayangnya, informasi yang beredar di kanal-kanal media sosial tak jarang mengandung framing dan bumbu tambahan, bahkan praktik memelintir informasi yang memicu kaburnya batas antara berita palsu dengan yang akurat.

Data Kemenkominfo menyebutkan bahwa ada sekitar 800.000 situs di Indonesia yang terindikasi sebagai penyebar informasi palsu. Pada 2014 saja, terdapat 761.126 situs yang diblokir karena konten berita palsu. Pada 2015 angkanya terus naik hingga mencapai 766.394 situs. Melengkapi data tersebut, menurut The Jakarta Post, sejak 2008 lalu sebanyak 144 orang telah diproses hukum karena kasus ujaran kebencian dan peredaran berita palsu di jagad media sosial.

Salah satu hal yang menarik untuk didiskusikan adalah banyaknya warganet yang merasa berhak untuk berujar apapun di media sosial dengan menggunakan payung pembenaran kebebasan berpendapat. Kebebasan berpendapat sendiri sejatinya memang merupakan hak asasi manusia yang dilindung oleh Pasal 19 Deklarasi Universal HAM dan Pasal 28E UUD 1945, yang mencakup kebebasan untuk berpendapat tanpa intervensi dan untuk mencari, menerima, dan berbagi informasi dan ide melalui media apapun dan tanpa memandang batas negara. Sayangnya, tidak semua orang menyadari bahwa hak kebebasan tersebut tidak absolut karena diiringi oleh tanggung jawab khusus. 
Tulisan ini kemudian ingin mendiskusikan peran literasi digital sebagai cara untuk mencegah praktik kebebasan berpendapat yang tidak bertanggung jawab di media sosial, khususnya penyebaran berita palsu (hoax). Tulisan ini akan mengelaborasi bagaimana literasi digital dapat membantu warganet di Indonesia untuk mengontrol diri dalam berinteraksi di media sosial. Literasi digital dapat memberikan kontribusi positif bagi masyarakat untuk melangkah lebih jauh yaitu menjadi garda depan iklim media sosial yang lebih sehat.

Permasalahan yang akan penulis angkat adalah bagaimana kecakapan literasi digital dibutuhkan sebagai upaya mengatasi hoax di media sosial. Tulisan ini akan dijelaskan dalam beberapa sub bahasan untuk menjelaskan urgensi literasi digital sebagai self control dalam menghadapi hoax, sebagai bentuk kebebasan berpendapat yang tidak bertanggung jawab. Pertama, akan dijelaskan definisi dan arti penting literasi digital. Kedua, tulisan ini akan menjelaskan mengenai darurat literasi digital pada pengguna media sosial. Ketiga, pembahasan tentang relasi literasi digital dengan upaya mengatasi hoax di era post-truth. Keempat, akan dijabarkan mekanisme kecakapan literasi digital yang dibutuhkan sebagai upaya meningkatkan self-control warganet. Titik tekan literasi ini sebagai upaya preventif untuk mencegah praktik kebebasan berpendapat yang tidak bertanggung jawab berupa berita palsu (hoax).

\section{TINJAUAN PUSTAKA}

\section{Literasi Media Potter}

Kata "literasi", yang bermakna kemampuan untuk membaca dan menulis, secara perlahan memiliki perluasan makna dengan berkembangnya teknologi media hingga era digital. W. James Potter (2001:4) menjelaskan bahwa beberapa ahli memperluas makna literasi dari yang awalnya hanya literasi membaca, menjadi literasi visual (merujuk pada televisi dan film) serta literasi komputer. Ketiganya bukanlah sinonim untuk literasi media, namun hanya komponen yang berdiri sendiri. Literasi media, menggabungkan seluruh kemampuan spesifik tersebut dan tumbuh sebagai sesuatu yang lebih general. Konsep literasi yang awalnya hanya dikaitkan dengan media cetak, menjadi lebih kompleks dengan istilah literasi media karena berkaitan dengan pemprosesan informasi berupa menyaring, mencocokkan makna, serta mengonstruksi makna dari media (Potter, 2004:270).

Media literacy is a perspective that we actively use when exposing ourselves to the media in order to interpret the meaning of the messages we encounter. We build our perspective from knowledge structures, we need tools and raw material. The tools are our skills. The raw material is information from the media and from the world. Active use means that we are aware of the messages and are consciously interacting with them (Potter, 2001:4). 
Melalui definisi tersebut, literasi media menurut versi Potter dimaknai sebagai kemampuan interpretasi makna dari pesan yang membutuhkan struktur pengetahuan berupa keahlian sebagai alat, serta kekayaan informasi sebagai bahannya. Lebih jauh, Potter menjelaskan bahwa informasi yang dimaksud adalah informasi yang multidimensi. Tidak hanya berupa fakta yang bisa diakses melalui buku, surat kabar, dan artikel majalah saja -yang kemudian disebut sebagai informasi kognitif-, tetapi juga tipe lainnya berupa informasi emosional, informasi estetis, dan informasi moral (Potter, 2001:8).

Tabel 1.

Tipe-tipe Informasi

\begin{tabular}{|l|l|l|l|}
\hline \multicolumn{1}{|c|}{$\begin{array}{c}\text { Domain } \\
\text { Informasi }\end{array}$} & \multicolumn{1}{|c|}{ Inti } & \multicolumn{1}{|c|}{$\begin{array}{c}\text { Teningkat } \\
\text { Literasi }\end{array}$} \\
\hline Kognitif & Informasi faktual & Tanggal, nama, definisi, dll. & Tinggi \\
\hline Emosional & Perasaan & $\begin{array}{l}\text { Cinta, benci, kebahagiaan, } \\
\text { frustasi, takut, nafsu, dll. }\end{array}$ & Rendah \\
\cline { 2 - 4 } & $\begin{array}{l}\text { Ambivalensi, kebingungan, } \\
\text { kewaspadaan, dll. }\end{array}$ & Tinggi \\
\hline Estetik & $\begin{array}{l}\text { Bagaimana } \\
\text { memproduksi } \\
\text { pesan; } \\
\text { kemampuan } \\
\text { apresiasi. }\end{array}$ & $\begin{array}{l}\text { Seberapa baik penulis, } \\
\text { fotografer, aktor, dan tim } \\
\text { kreatif termasuk editor } \\
\text { bekerja. }\end{array}$ & Tinggi \\
\hline Moral & $\begin{array}{l}\text { Nilai } \\
\text { nenilaian terhadap benar- }\end{array}$ & Tinggi \\
\hline
\end{tabular}

Sumber: Potter (2001:8)

Dengan berkembangnya era digital, barulah muncul istilah literasi digital yang selanjutnya dimaknai dengan kemampuan untuk memahami informasi berdasarkan format digital seperti kata-kata, rekaman suara, dan gambar yang melebur jadi satu. Bahan-bahan kombinasi ini yang kerapkali diistilahkan dengan "multimedia" memang bukan hal baru, namun bahan-bahan penyusunnya lah yang hadir dengan cara baru. Warganet dimungkinkan mengubah, memformat ulang, mentransformasikan gambar, suara, dan kata-kata secara bebas (Lanham, 1995:198).

\section{Era Post-Truth}

Berbicara mengenai literasi digital tidak dapat dilepaskan dari era post-truth. Era posttruth hadir sebagai hasil dari meningkatnya polarisasi, ketidaksetaraan pertumbuhan ekonomi, penolakan kepercayaan pada ilmu pengetahuan, dan meningkatnya fraksi lanskap media (Lewandowsky, 2017:353). Transformasi lanskap media yang terjadi pada era media baru tersebut secara tidak langsung menjadi salah satu penyebab munculnya era post-truth. Korelasi antara pesatnya penggunaan media sosial dan segala 
dinamikanya terhadap hangatnya pembicaraan mengenai post-truth menurut Lewandowsky (2017:359) dilatarbelakangi oleh beberapa alasan.

Pertama, fleksibilitas dan fraksi yang ditawarkan oleh media sosial memungkinkan masyarakat untuk memilih apa yang mereka favoritkan (echo-chamber) sehingga kebanyakan informasi yang mereka akses cocok dengan pandangan yang telah ada. Konsekuensinya, ada kemungkinan pembentukan keyakinan yang keliru ketika bukti relevan dipahami secara tidak tepat (Garrett, Weeks, \& Neo, 2016 dalam Lewandowksy, 2017:359). Custom-deliver content yang selaras dengan kesukaan dan perilaku pengguna, secara cepat menciptakan realitas epistemik alternatif, atau banyak disebut sebagai "filter bubbles".

Kedua, beragamnya pilihan menyebabkan besarnya heterogenitas tingkatan misinformasi mengenai isu penting. Dalam hal ini, kecenderungan media yang diakses khalayak mencerminkan ketertarikan isu mereka sehingga terjadi pengabaian terhadap banyak isu yang lebih penting.

Ketiga, jarak psikologis dalam diskusi online yang sarat akan kebebasan cara bertutur dan erat kaitannya dengan kesan ketidaksopanan, memantik terbentuknya polarisasi kelompok. Ada interaksi interpersonal yang negatif dan terjadinya social chaos akibat fenomena internet troll (orang atau konten pesan yang bertujuan membangkitkan tanggapan emosional dari pengguna lainnya).

Pembahasan mengenai faktor-faktor pemicu munculnya era post-truth dari media sosial tidak berhenti sampai di sana. Pandangan distopian akan masa depan yang kebenarannya dikendalikan oleh suara mayoritas di media sosial masih menjadi sebuah kemungkinan yang nyata. Diskusi publik mengenai post-truth dan kaitannya dengan berita palsu (hoax) yang sebelumnya tak banyak dibicarakan hingga 2016, tiba-tiba menjadi topik yang sangat hangat untuk dibicarakan. Pada era post-truth, Bu \& Xia (2013) dalam Lewandowsky (2017:354) menyinggung bahwa kekuatan berada pada pihak yang paling vokal dan berpengaruh pada media sosial: dari selebritis dan perusahaan besar, hingga akun botnet yang dapat menggerakkan jutaan tweetbots atau sock puppets (sosok akun palsu yang digawangi oleh kelompok kecil operator yang dapat membuat ilusi opini yang menyebar luas).

\section{METODE PENELITIAN}

Studi ini menggunakan metode kepustakaan (library research) dalam mengelaborasi berbagai macam literatur baik berupa buku, jurnal, majalah, maupun literatur yang relevan dengan tema tulisan. Metode kepustakaan ini dipilih dikarenakan ingin memadukan hasil temuan bertema sama sebagai kajian pendahuluan (preliminary studies) dengan kajian kekinian (Zed, 2008: 2). Dalam studi ini, akan dilakukan 
penyesuaian terhadap ekologi media yang sudah berubah sehingga mendorong adanya unsur kebaruan (novelty) dari studi terdahulu.

\section{HASIL DAN PEMBAHASAN}

\section{Literasi Digital: Sebuah Keharusan dalam Kehidupan Komunikasi}

Literasi digital memiliki arti penting dalam kehidupan komunikasi karena tiga alasan. Pertama, penggunaan media digital khususnya internet dan media sosial yang semakin intens dalam kehidupan sehari-hari. Rasanya, gawai menjadi perangkat yang tidak boleh tertinggal serta menjadi media yang paling diandalkan sebagai sarana berkomunikasi serta mencari informasi. Media digital berkembang dengan sangat cepat, dengan tawaran informasi dan konten lainnya yang terus menerus diproduksi tanpa mengenal batasan jarak dan waktu. Pembaharuan informasi bahkan terjadi dalam hitungan detik, dari banyak sumber dan platform yang tersedia.

Kedua, ketergantungan masyarakat terhadap situs mesin pencari (Google, Yahoo, atau Bing) dan platform media sosial untuk mencari informasi. Tampaknya, internet menjadi media baru yang menawarkan solusi atas segala pencarian informasi masyarakat. Internet menjadi unggul karena waktu penyediaan informasi yang cepat dan kemudahan aksesnya. Demikian halnya dengan media sosial sebagai kanal akses informasi alternatif. Ketiga, untuk menyeleksi informasi dari banyaknya sumber yang ada, individu memerlukan kecakapan atau kemampuan spesifik. Dengan tersedianya aneka jenis informasi, perlu adanya kecakapan khusus yang ditunjang dengan literasi digital. Dengan memiliki kecakapan tersebut, individu akan memiliki kontrol lebih pada proses interpretasi pesan sehingga dapat menyeleksi informasi/konten tertentu yang akurat.

Lalu, apa pengertian literasi digital sebenarnya? Pada literasi terdahulu era media cetak, ide dan ekspresi pada hakikatnya hanya terdiri dari satu bentuk. Pemaknaan dilakukan terhadap kata-kata. Sedangkan literasi digital, bentuk ekspresinya menggunakan kode digital yang menghasilkan suara, gambar, dan kata-kata, sehingga ada variasi parametrik yang berlaku pada inti dari ekspresi digital. Untuk dapat terliterasi digital, harus ada kemampuan untuk menguraikan gambar yang kompleks dan suara, serta makna sintaksis kata-kata. Literasi digital juga meningkatkan kemampuan kita untuk mencocokkan media pada informasi yang ditawarkan untuk khalayak (Lanham, 1995: 199). Pada studi lebih lanjut, proses literasi digital ini melibatkan multi-teks yang otentik, diproses dengan beragam perangkat dan perpindahan kode untuk memahami konten dari banyak pengguna pada subjek tunggal (Chase, 2011: 536).

Mengembangkan definisi literasi media yang dicetuskan oleh Potter (dalam Adiputra, 2008:5), penulis mencoba membagi definisi literasi digital ke dalam tiga kategori serupa (dengan mengganti obyek media menjadi teknologi digital). Pertama, umbrella definition, yang dapat digunakan untuk menganalogikan literasi digital sebagai pelindung individu 
ketika individu terkena hujan informasi sewaktu berhadapan dengan internet dan media sosial. Dalam perkembangannya, dengan jumlah informasi yang terus diproduksi setiap detik dan tak terhingga, informasi bahkan tak hanya cukup dianalogikan sebagai hujan namun sampai tsunami informasi. Kedua, definisi proses, menunjukkan bahwa literasi digital adalah sebuah kecakapan yang berfungsi ketika individu berselancar pada media sosial dan konten internet lainnya. Ketiga, definisi tujuan, menganalogikan literasi digital sebagai sebuah hasil akhir dari konstruksi yang dibangun dalam pikiran individu sehingga individu tersebut memiliki kontrol yang lebih besar atas pesan media yang ia akses, dalam hal ini media digital berupa internet dan media sosial.

Kebutuhan literasi digital ini melibatkan kompetensi teknologi, kognitif, dan sosial dalam menghadapi perubahan teknologi digital. Pengguna harus terliterasi digital supaya bisa menguasai tantangan sosiologis, kognitif, dan pedagogis akibat meningkatnya penetrasi internet. Kemampuan ini meliputi: kemampuan mengoperasikan komputer dan mengakses secara efektif, menguasai informasi dalam jumlah besar, mengevaluasi reliabilitas informasi, dan secara kritis menilai perangkat teknologi secara alami. Individu harus belajar, berkolaborasi, dan memecahkan masalah secara efektif pada lingkungan virtual, dan berkomunikasi secara efektif pada lingkungan sosial yang termediasi teknologi. Tak sebatas itu saja, literasi digital juga berkaitan dengan isu-isu dinamika informasi, properti dan kepemilikan intelektual, copyright, keaslian konten, dan plagiarisme (Eshet-Alkalai, 2012:1).

Tujuan memiliki kemampuan literasi digital ialah untuk memberikan kontrol lebih pada khalayak dalam memaknai pesan yang berlalu-lalang di media digital. Keseluruhan pesan media memiliki makna yang terlihat, disertai dengan banyak makna yang lebih dalam tersimpan di dalamnya. Perbedaan tingkat literasi tentu saja akan berdampak pada perbedaan kontrol individu dalam proses interpretasi informasi yang ada.

Menurut Potter (2001: 10), individu dengan tingkat literasi yang rendah akan cenderung mudah menerima makna pesan yang tampak, yang dibuat dan ditentukan oleh media. Dengan keterbatasan perspektif, ia memiliki struktur pengetahuan yang lebih kecil, dangkal, dan kurang terorganisir, sehingga tidak mumpuni untuk digunakan dalam proses interpretasi makna pesan media. Akhirnya, individu tersebut akan sangat sulit untuk mengidentifikasi keakuratan informasi, menyortir kontroversi, menyadari konten satir, serta mengembangkan cara pandang yang lebih luas.

Sebaliknya, Potter (2001:10) menjelaskan bahwa pada individu dengan tingkat literasi media yang tinggi, ia akan secara aktif menggunakan serangkaian kemampuan interpretasi. Individu tersebut menempatkan pesan media pada konteks struktur pengetahuan yang terelaborasi dengan baik. Akhirnya, ia mampu menginterpretasi pesan apapun dari banyak dimensi yang berbeda, sehingga menyediakan lebih banyak pilihan makna. Ketika individu memiliki tingkat literasi tinggi, ia mengetahui bagaimana menyeleksi semua pilihan makna dan memiliki kuasa dan kontrol lebih untuk memilih 
salah satu yang paling akurat dari beberapa sudut pandang (kognitif, emosional, estetik, dan moral).

Apabila kita secara sadar memilih terpaan media tertentu dan secara aktif mengatur informasi yang paling akurat dari terpaan tersebut, secara tidak langsung kita sedang membangun dan memperkokoh struktur pengetahuan. Dengan kuatnya struktur pengetahuan dan keahlian yang kita miliki, kita dapat meningkatkan apresiasi terhadap media baru. Semakin terliterasi, semakin kita memahami dan mengapresiasi media baru, pesan, dan efeknya.

\section{Darurat Literasi Digital pada Pengguna Media Sosial}

Literasi digital tidak dapat dipisahkan dari dunia media sosial karena 97,4\% orang Indonesia mengakses akun media sosial saat menggunakan internet. Dalam menggunakan media sosial, tidak semua orang menggunakannya dengan bijak karena merasa punya hak untuk bebas berpendapat. Pada akhirnya, muncul kasus-kasus kebebasan berpendapat yang tidak bertanggung jawab di media sosial.

Menurut data yang dihimpun oleh perusahaan riset We Are Social, pertumbuhan jumlah pengguna internet turut diiringi oleh meningkatnya jumlah pengguna layanan media sosial. Hanya berjumlah 79 juta pada 2016, angka tersebut setahun berikutnya naik menjadi 106 juta pengguna. Para pengguna yang secara aktif menggunakan media sosial di perangkat mobile pun naik dari angka 66 juta menjadi 92 juta. Dari segi pertambahan jumlah pengguna di layanan media sosial tersebut, Indonesia bahkan menempati posisi ketiga di dunia. Kita berhasil mengalahkan negara-negara seperti Brazil dan Amerika Serikat, dan hanya kalah dari Cina dan India. Khusus untuk jumlah pengguna Facebook, We Are Social mengklaim kalau Indonesia masih menempati posisi keempat dalam daftar negara dengan pengguna Facebook terbanyak, dengan jumlah seratus enam juta pengguna. Indonesia hanya kalah dari Amerika Serikat, India, dan Brazil (Pratama, 2017).

Tak jarang, individu mengelola lebih dari satu platform media sosial. Hal ini dilakukan karena karakteristik tiap platform yang unik dan berbeda. Menurut Kaplan dan Haelin (2010:63), media sosial memiliki beberapa jenis platform yang dikelompokkan menjadi:

1. Collaborative projects, dimana semua orang bisa menulis, mengedit, dan menambah isinya. Butuh klarifikasi mendalam ketika mengakses informasi dari wadah ini. Contoh: Wikipedia.

2. Content communities, para pengguna dapat memuat, menonton, dan berbagi konten secara gratis. Contoh: YouTube.

3. Blogs dan Mikroblogs: apikasi yang sederhana hanya dengan mengunggah konten singkat yang menjadi daya tarik penggunanya. Contoh: Twitter.

4. Social Networking Sites (SNS): layanan jejaring sosial yang memungkinkan untuk saling berbagi foto, video, dan informasi lainnya kepada lingkungan pertemanan virtual. Contoh: Facebook dan Instagram.

5. Virtual Game Worlds: dunia permainan secara daring, biasa disebut online gaming. 
6. Virtual Social Worlds: simulasi kehidupan yang terjadi dalam dunia virtual. Contoh: Second Life.

Selanjutnya, Kaplan dan Haelin (2010:62) mengklasifikasikan media sosial berdasarkan kehadiran sosial/ kekayaan media dan presentasi diri/ penyingkapan diri melalui tabel berikut.

Tabel 2.

Klasifikasi Media Sosial

\begin{tabular}{|c|c|c|c|c|}
\hline & \multicolumn{3}{|c|}{ Social Presence/Media Richness } \\
\hline & & Low & Medium & High \\
\hline \multirow[t]{2}{*}{$\begin{array}{l}\text { Self- } \\
\text { presentation/self- } \\
\text { disclosure }\end{array}$} & High & Blogs & $\begin{array}{l}\text { SNS (Facebook } \\
\text { dan Instagram) }\end{array}$ & $\begin{array}{lr}\text { Virtual } & \text { Social } \\
\text { Worlds } & \text { (Second } \\
\text { Life) } & \end{array}$ \\
\hline & Low & $\begin{array}{l}\text { Collaborative } \\
\text { projects } \\
\text { (Wikipedia) }\end{array}$ & $\begin{array}{l}\text { Content } \\
\text { communities } \\
\text { (YouTube) }\end{array}$ & $\begin{array}{l}\text { Virtual Game } \\
\text { Worlds (World of } \\
\text { Warcraft) }\end{array}$ \\
\hline
\end{tabular}

Sumber: Kaplan dan Haelin (2010:62)

Penggunaan media sosial dengan berbagai platform ini disebut-sebut sebagai wadah kebebasan berpendapat di jagad dunia virtual. Kebebasan berpendapat, yang dijamin oleh Pasal 19 Deklarasi Universal HAM dan Pasal 28E UUD 1945 mencakup kebebasan untuk berpendapat tanpa intervensi dan untuk mencari, menerima, dan berbagi informasi dan ide melalui media apapun dan tanpa memandang batas negara. Kebebasan ini terdiri dari dua bentuk, yaitu kebebasan berpendapat dan berekspresi. Pada kebebasan berpendapat, individu berhak menuangkan opininya dalam ucapan, tulisan, atau lain sebagainya. Sedangkan kebebasan berekspresi mencakup ekspresi yang lebih luas, termasuk melalui materi audiovisual, ekspresi budaya (tarian dan lagu), artistik maupun politik, serta gerakan lainnya melalui tagar dan aksi sosial. Semua ini menjadi lebih mudah dilakukan dengan perantara media sosial.

Meski demikian, penggunaan media sosial sebagai kanal kebebasan berpendapat tetap diasosiasikan pada keuntungan dan kerugian. Di satu sisi, media sosial dapat dilihat sebagai satu langkah lebih dekat dengan demokrasi pada internet, dan menutup kesenjangan digital antara negara berkembang dan negara maju. Akses pada informasi dan dukungan sosial dapat meningkat. Mengingat karakteristik masyarakat Indonesia yang memiliki keterikatan sosial yang tinggi, penggunaan media sosial seperti Facebook dan Twitter menjadi populer.

Namun di sisi lain, beberapa kasus negatif ditemukan dalam ranah kebebasan berpendapat seiring intensnya penggunaan media sosial di masyarakat. Berdasarkan data dari Diskominfo Jabar 2012, saluran penyebaran berita hoax sebanyak 92,4\% ditemukan melalui media sosial. Oleh sebab itu, relasi literasi digital dengan upaya 
mengatasi kasus hoax perlu lebih banyak digali terutama pada golongan media sosial dengan kasus hoax terbanyak yaitu jenis mikroblog (Twitter) dan SNS (Facebook dan Instagram).

\section{Literasi Digital: Upaya Mengatasi Hoax di Era Post-Truth}

Sebenarnya, istilah "post-truth" dan "post-fact" adalah istilah yang relatif baru mengingat secara virtual terma tersebut tidak dikenal pada 5 tahun yang lalu. Meski sebenarnya sudah muncul sejak tahun 1992 (dicetuskan oleh Steve Tesich), tulisan mengenai posttruth baru muncul kembali tahun 2004 oleh Ralph Keyes. Namun belakangan, pencarian akan terma ini semakin tinggi bahkan dinominasikan sebagai the word of the year pada 2016 oleh Oxford Dictionary -tahun dimana Inggris Raya melepaskan diri dari Uni Eropa dan terpilihnya Donald Trump sebagai presiden Amerika Serikat. Kamus Oxford sendiri mendefinisikan istilah tersebut sebagai situasi dimana fakta objektif menjadi kurang berpengaruh dalam membentuk opini publik dibanding emosi dan keyakinan personal.

Dalam dua momen tersebut, informasi hoax punya pengaruh yang jauh lebih besar ketimbang fakta yang sebenarnya. Selama kampanye pemilihan presiden Amerika Serikat pada 2016 misalnya, lembaga pemeriksa fakta independen PolitiFact menilai bahwa 70\% pernyataan Donald Trump adalah bohong. Sebagai pembanding, Hillary Clinton yang menjadi pesaingnya memiliki angka kebohongan yang jauh lebih rendah pada kisaran 26\%. Meski demikian, Donald Trump keluar sebagai pemenang sehingga mencerminkan bahwa rendahnya akurasi konten kampanye yang ia sampaikan tidak mengurangi daya tariknya untuk mendulang banyak pemilih (Lewandowsky, 2017:354).

Dalam kasus kebebasan berpendapat, berita hoax ini ditengarai menjadi cara untuk melakukan propaganda (Yates, 2016). Hoax atau berita palsu didefinisikan sebagai informasi yang tersebar melalui media, seringkali untuk mengambil keuntungan pada aktor sosial yang spesifik, yang terbukti mengandung materi yang tidak benar. Kabar bohong yang beredar di media sosial menjadi besar ketika diambil oleh situs atau akun terkemuka yang memiliki banyak pengikut. Berita ini cenderung menyebar dengan cepat karena fitur shareability yang tinggi pada media sosial.

Tingginya pertumbuhan informasi palsu yang beredar di era post-truth sedikit banyak sudah terlihat dampaknya pada masyarakat. Individu/kelompok yang dengan sengaja memproduksi informasi palsu biasanya memiliki banyak dalih untuk menyelamatkan diri dari cap "pembuat berita palsu". Sejalan dengan gagasan Ralph Keyes bahwa daripada menerima kebohongan sebagai cara baru kehidupan, muncul manipulasi gagasan mengenai kebenaran. Mulai dari "membuat pesan" kebenaran, kemudian "mempercantiknya", jadilah cerita tentang "improvisasi kebenaran" (Keyes, 2004:14). Dari kronologi tersebut, fenomena kebohongan akhirnya selalu memiliki cara untuk dipelintir. Para era post-truth, batasan antara kebenaran dan kebohongan menjadi kabur, demikian juga dengan kejujuran dan ketidakjujuran, fiksi dan nonfiksi. Menipu orang lain menjadi sebuah tantangan, permainan, dan kebiasaan. 
Informasi palsu pada era post-truth tidak lagi dapat dipandang sebagai kegagalan kognitif individu yang dapat dikoreksi dengan perangkat komunikasi yang tepat. Lebih jauh, harus dipertimbangkan pengaruh epistemologi alternatif yang menentukan standar konvensional akan bukti. Respon terhadap era post-truth harus melibatkan solusi teknologi yang menggabungkan prinsip psikologi, pendekatan interdisipliner yang dideskripsikan sebagai "technocognition".

Relasi literasi digital dalam memberantas berita palsu ini terletak pada peran kemampuan kognitif khalayak dalam proses verifikasi informasi. Bahkan, pada tingkatan yang lebih tinggi, literasi digital dapat membantu individu memberikan informasi alternatif atas informasi yang sudah terkonfirmasi kepalsuannya. Dalam penelitiannya, Jonas De Keersmacker (2017:107) menyebutkan bahwa derajat pembenaran yang dilakukan individu tergantung pada kemampuan kognitif mereka. Individu dengan kemampuan kognitif lebih rendah cenderung kurang responsif untuk mengoreksi informasi palsu dibandingkan mereka dengan kemampuan kognitif tinggi.

Pada era ini, peran literasi digital dalam konteks media sosial menjadi lebih sentral. Bila kontrol konten media sosial rasanya sulit dilakukan oleh pemilik media, pemerintah, maupun kelompok lainnya, literasi digital adalah salah satu solusinya. Dengan menggalakkan literasi digital, pengendalian diri terhadap penggunaan media sosial dapat dilakukan secara optimal. Literasi digital bertujuan agar masyarakat menguasai pemprosesan berbagai informasi di media sosial dengan lebih kritis dan tidak mudah mengikuti arus tren informasi yang belum tentu valid.

\section{Kecakapan Literasi Digital untuk Meningkatkan Self-control Warganet}

Hoax menjadi salah satu bentuk tindak kriminal yang terjadi karena rendahnya selfcontrol individu. Teori self-control yang berkaitan erat dengan perbuatan kriminal ini sebenarnya memiliki asumsi pokok bahwa setiap orang memiliki tendensi yang berbeda untuk melakukan tindak kriminal, bagaimanapun keadaannya, karena kadar kontrol yang berbeda pada individu satu dengan individu lainnya. Mereka yang memiliki kadar self-control yang tinggi akan cenderung memiliki kemungkinan kecil untuk terlibat dalam tindak kriminal. Sedangkan pada mereka yang rendah, dipadukan dengan situasi yang mendukung akan lebih mudah melakukan kejahatan. Tindak kriminal dan perilaku sejenis seperti merokok, minum-minuman keras, penggunaan narkoba, seks bebas, dan keadaan lainnya adalah manifestasi dari rendahnya self-control pada individu. Penyebab rendahnya self-control adalah sosialisasi yang tidak komplit dan tidak efektif (Akers, 191:202).

Rendahnya self-control individu ini didukung juga dengan situasi media sosial yang masih ramai dengan konten negatif. Sehingga, individu yang memiliki self-control dengan kadar rendah merasa bukan sebuah hal yang besar ketika dia 'ikut-ikutan' membuat berita palsu dan menyebarkan berita palsu karena kaburnya batas fakta dan opini pada era post-truth. Meski sudah ada berbagai aturan dan anjuran untuk menjauhi 
pelanggaran tersebut, nyatanya masih kurang efektif untuk meminimalisasi terjadinya kasus yang sama. Kasus yang banyak terjadi, aturan tersebut berfungsi hanya kepada pelanggarnya (represif) -meski cenderung menangani kasus yang dilaporkan saja-, bukan sebagai upaya pencehagan (preventif).

Kurang efektifnya aturan-aturan tersebut ditengarai karena proses sosialisasi pada masyarakat masih belum terjadi secara optimal. Meski sudah ada UU ITE, bahkan Fatwa MUI mengenai bermuamalah pada media sosial, tetapi berapa banyak warganet yang mengerti tentang isi dan konsekuensinya jika melanggar? Padahal, aspek sosialisasi ini berperan penting untuk meningkatkan self-control individu. Untuk itu, sosialisasi melalui literasi digital menjadi hal yang krusial dilakukan pada era digital ini, khususnya memasuki era post-truth.

Literasi digital yang memberi titik tekan pada kemampuan kritis individu dalam menggunakan media digital, dalam hal ini juga termasuk media sosial, berpijak pada pemprosesan informasi dan melibatkan kompetensi teknologi, kognitif, dan sosial. Hal tersebut perlu dilakukan agar warganet lebih peka ketika menyaring informasi dan cakap dalam membedakan informasi akurat dan tidak. Literasi digital dapat menjadi alternatif cara yang efektif, dengan mengenalkan tanda-tanda berita palsu, prosedur verifikasi informasi, hingga menindak lanjuti informasi yang kiranya masuk kategori hoax.

Lalu, bagaimana cara meningkatkan kecakapan literasi digital? Secara teoritis, individu dengan tingkat literasi yang tinggi harus mendapatkan asupan informasi yang baik, kemudian mengaturnya menjadi struktur pengetahuan yang berguna. Namun dalam praktiknya, meningkatkan kecakapan literasi digital perlu dilakukan sedini mungkin.

Pengenalan literasi digital pada dunia akademik dapat dimulai dari sosialisasi kurikulum literasi. Seperti peta kurikulum yang ditawarkan oleh UNESCO, perlu adanya literasi akademik yang menyasar pada guru, salah satunya agar guru dapat secara kritis mengevaluasi konten media dan mengevaluasi informasi yang beredar (Grizzle dkk, 2011:18).

Selain upaya tersebut, strategi personal yang dapat dilakukan untuk meningkatkan literasi digital, yang diadopsi dari pemikiran Potter (2004:378) juga dapat diterapkan. Pertama, mengembangkan kesadaran akurat akan paparan informasi dengan memilah sumber yang kredibel. Kedua, terus memperkaya diri dengan ilmu agar struktur pengetahuan yang kita bangun menjadi lebih kuat. Ketiga, membandingkan informasi yang sama dari satu platform media ke media lainnya agar bisa mendapatkan banyak sudut pandang. Keempat, berkaca pada opini pribadi, apakah opini tersebut sudah cukup rasional dengan segala sumber informasi yang kita punya. Terakhir, menumbuhkan budaya verifikasi dan aktif mengoreksi informasi palsu yang beredar. 
Literasi digital ini dapat diterapkan untuk menciptakan filter manual pada peredaran informasi di media sosial. Ketika permasalahan sistem dan algoritma digital tidak mampu memberikan iklim yang sehat pada lalu-lintas informasi media sosial, peran akun-akun yang dijalankan oleh manusia kemudian harus bekerja secara aktif. Dengan fitur report, setiap akun pada media sosial akhirnya memiliki otoritas dalam melaporkan gejala berita palsu yang mereka temukan. Sehingga, sistem yang ada dalam media sosial bisa menindaklanjuti temuan tersebut dengan secara otomatis memblokir akun ataupun menyematkan simbol konten sensitif. Pada tahapan yang lebih lanjut, masyarakat juga bisa memanfaatkan layanan aduan konten yang disediakan oleh Kementrian Komunikasi dan Informatika dengan mengirimkan e-mail ke alamat aduankonten@mail.kominfo.go.id. Apabila tahapan ini berhasil dilakukan, perlahanlahan iklim media sosial akan berkembang menjadi lebih sehat.

\section{SIMPULAN}

Peningkatan literasi digital sebagai bentuk self control menjadi solusi untuk mencegah kasus peredaran informasi palsu (hoax) menjadi berulang dan semakin banyak. Literasi digital dapat menjadi cara yang efektif untuk menanggulangi informasi palsu (hoax) di era post-truth, dengan mengenalkan tanda-tanda berita palsu, prosedur verifikasi informasi, hingga menindaklanjuti informasi yang kiranya masuk kategori hoax. Para era post-truth, batasan antara kebenaran dan kebohongan menjadi kabur, demikian juga dengan kejujuran dan ketidakjujuran, fiksi dan nonfiksi, sehingga menjadi sebentuk tantangan tersendiri bagi pengguna media sosial.

Literasi digital yang memberi titik tekan pada kemampuan kritis individu dalam menggunakan media digital, dalam hal ini juga termasuk media sosial, berpijak pada pemprosesan informasi dan melibatkan kompetensi teknologi, kognitif, dan sosial. Hal tersebut perlu dilakukan agar warganet lebih peka ketika menyaring informasi dan cakap dalam membedakan informasi akurat dan tidak.

Untuk menumbuhkan literasi digital pada level individu, kita bisa melakukan upaya dalam beberapa cara. Pertama, mengembangkan kesadaran akurat akan paparan informasi dengan memilah sumber yang kredibel. Kedua, terus memperkaya diri dengan ilmu agar struktur pengetahuan yang kita bangun menjadi lebih kuat. Ketiga, membandingkan informasi yang sama dari satu platform media ke media lainnya agar bisa mendapatkan banyak sudut pandang. Keempat, berkaca pada opini pribadi atas sebuah isu, apakah opini tersebut sudah cukup rasional dengan segala sumber informasi yang kita punya. Terakhir, menumbuhkan budaya verifikasi dan aktif mengoreksi informasi palsu yang beredar.

Upaya literasi digital hingga saat ini merupakan cara terbaik untuk menanggulangi hoax sebagai salah satu bentuk kebebasan berpendapat yang tidak bertanggung jawab. Perlu 
sosialisasi secara menyeluruh agar dapat tercipta ketahanan sosial, warganet yang cerdas dan selektif dalam memilah informasi, demi iklim media sosial yang lebih sehat.

\section{DAFTAR PUSTAKA}

Adiputra, Wisnu Martha. 2008. Literasi Media dan Interpretasi atas Bencana. Jurnal Ilmu Sosial dan Ilmu Politik, 11 (3), 1-20. Diakses melalui https://jurnal.ugm.ac.id/jsp/article/view/10992

Akers, R. 1991. Self-Control as a General Theory of Crime. Journal of Quantitative Criminology, 7(2), 201-211. Diakses melalui http://www.jstor.org/stable/23365747

Chase, Z., \& Laufenberg, D. 2011. Embracing the Squishiness of Digital Literacy. Journal of Adolescent \& Adult Literacy, 54(7), 535-537. Diakses melalui http://www.jstor.org/stable/41203403

Eshet-Alkalai, Yoram \& Soffer, 0. 2012. Guest Editorial - Navigating in the Digital Era: Digital Literacy: Socio-Cultural and Educational Aspects. Journal of Educational Technology \& Society, 15(2), 1-1. Diakses melalui http://www.jstor.org/stable/jeductechsoci.15.2.1

Grizzle, A., Wilson, C., Tuazon, R., \& Cheung C.K (eds). 2011. Media and Information Literacy. Curriculum for Teachers. UNESCO.

Kaplan, Andreas M. \& Haenlein, Michael. 2010. Uses of the World, Unite! The Challenges and Opportunities of Social Media. Business Horizons, 53 (1), 59-68. Diakses melalui

https://www.sciencedirect.com/science/article/pii/S0007681309001232

Keersmacker, Jonas De \& Roets, Arne. 2017. 'Fake News': Incorrect, but hard to correct. The Role of Cognitive Ability on the Impact of False Information on Social Impressions. Diakses melalui Intelligence 65, p. 107-110.

Keyes, Ralph. 2004. The Post-Truth Era: Dishonesty and Deception in Contemporary Life. New York: St Martin's Press.

Lanham, R. 1995. Digital Literacy. Scientific American, 273(3), 198-200. Diakses melalui http://www.jstor.org/stable/24981795

Lewandowsky, Stephan dkk. 2017. Beyond Misinformation: Understanding and Coping with the "Post-truth" Era. Diakses melalui Journal of Applied Research in Memory and Cognition 6, p. 353-369. 
Oxford, 2016. Word of the Year. https://en.oxforddictionaries.com/word-of-theyear/word-of-the-year-2016

Potter, W. James. 2001. Media Literacy $2^{\text {nd }}$ Edition. California: Sage Publications.

Potter, W. James. 2004. Argument for the Need for a Cognitive Theory of Media Literacy. American Behavioral Scientist, 48 (2), 266-272. Diakses melalui http://journals.sagepub.com.ezproxy.ugm.ac.id/doi/pdf/10.1177/0002764 204267274

Pratama, Aditya Hadi. 2017. Perkembangan Pengguna Internet di Indonesia Tahun 2016 Terbesar di Dunia. Diakses melalui https://id.techinasia.com/pertumbuhanpengguna-internet-di-indonesia-tahun-2016

Roese, V. 2018. You won't believe how co-dependent they are: Or: Media hype and the interaction of news media, social media, and the user. In Vasterman P. (Ed.), From Media Hype to Twitter Storm: News Explosions and Their Impact on Issues, Crises, and Public Opinion (pp. 313-332). Amsterdam: Amsterdam University Press. Diakses melalui http://www.jstor.org/stable/j.ctt21215m0.19

Van Dijck, José. 2013. The Culture of Connectivity. A Critical History of Social Media. New York: Oxford University Press.

Yates, Simeon. 2016. 'Fake News' - Why People Believe It and What Can Be Done to Counter It. Diakses melalui https://ethicaljournalismnetwork.org/fake-news-peoplebelieve-can-done-counter 